\title{
PENCAPAIAN IDENTITAS REMAJA DARI ORANG TUA TUNGGAL (Studi Kasus Orang Tua Tunggal )
}

\author{
Amril \\ Program Pasca Sarjana \\ Program Studi Magister Studi Islam \\ Universitas Muhammadiyah Yogyakarta \\ E-mail: amrilrabbani@gmail.com
}

\begin{abstract}
Abstrak
Penelitian ini bertujuan untuk mendeskripsikan pola asuh yang digunakan oleh para orang tua tunggal pada remaja khususnya untuk pencapaian identitas Achievement, juga untuk mengetahui peran orang tua tunggal dalam membentuk pencapaian identitas pada remaja, khususnya identitas achievement. Hasil penelitian ini menunjukan adanya peran orang tua tunggal untuk pencapaian identitas pada remaja ditandai dengan penggunaan pola asuh yang tepat. Pola asuh ini merupakan interaksi antara anak dengan orang tua selama mengadakan kegiatan pengasuhan. Terdapat tiga pola asuh orang tua terhadap anaknya, yaitu pola asuh demokratis, permisif, dan otoriter, namun dari hasil penelitian ini menunjukkan bahwa pola asuh demokratis adalah pola asuh yang tepat untuk membantu remaja dalam pencapaian identitas dirinya, khususnya identitas achievement.
\end{abstract}

Kata kunci: orang tua tunggal, identitas diri remaja, identitas achievement

\section{Abstract}

This study aims to describe the parenting patterns used by single parents in adolescents especially for achieving Achievement identity, also to know the role of single parents in shaping the achievement of identity in adolescents, especially the identity of achievement. The results of this study indicate the existence of a single parent role for the achievement of identity in adolescents characterized by the use of appropriate parenting patterns. This parenting pattern is an interaction between children and parents during holding parenting activities. There are three parenting patterns that parents apply to their children, namely democratic parenting, permissive, and authoritarian, the results of this study indicate that the pattern of foster democracy is the right parenting to help adolescents in achieving their identity, especially the identity of achievement.

Keywords: single parent, youth of identity, identity achievement

\section{Info Artikel}

Diterima Agustus 2018, disetujui September 2018, diterbitkan Desember 2018 


\section{PENDAHULUAN}

Menjadi single parent atau orang tua tunggal dalam sebuah keluarga tentu saja tidak mudah, terlebih bagi seorang ibu tunggal yang terpaksa mengasuh anaknya seorang diri, entah karena cerai dari suaminya atau suaminya meninggal dunia. Hal tersebut membutuhkan perjuangan berat untuk membesarkan anak, termasuk memenuhi kebutuhan keluarga. Orang tua tunggal menghadapi berbagai stress. Dalam survey nasional besar, baik pasangan yang tinggal bersama maupun orang tua tunggal.

Adapun yang lebih memberatkan lagi adalah anggapan-anggapan lain dari lingkungan sosial yang sering meremehkan single parent (orang tua tunggal), hal tersebut bisa jadi akan mempengaruhi kehidupan si anak. Bagi seorang Ibu, menjadi single parent merupakan pengalaman yang sangat berat. Terlebih lagi disaat-saat lingkugan tidak berpihak, terkadang seorang ibu takut jika hal tersebut dapat mempengaruhi perkembangan anak-anaknya, sehingga diperlukan sikap kuat dan tegar terhadap setiap tantangan hidupnya sebagai teladan bagi anak-anaknya. Seperti yang dialami oleh wanita yang bercera, agi mereka masalah sosial lebih sulit diatasi dibandingkan pada seorang pria yang yang menduda. Wanita yang diceraikan bukan hanya dikucilkan dari kegiatan sosial tetapi lebih buruk lagi, wanita seringkali kehilangan teman lamanya.
Peran remaja dalam mewujudkan kesiapan dirinya untuk menjadi penerus bangsa sangatlah berat. Dalam mengemban tanggung jawab estafet peradaban tersebut, remaja harus bisa untuk mengembangkan segala potensi yang dimiliki. Salah satu upaya dalam mengembagkan segala potensi yang dimiliki oleh remaja adalah pencapaian yang komprehensif atas identitas diri remaja. Erikson menganggap bahwa identitas diri pada remaja dapat dijadikan salah satu acuan pencapaian pribadi utama di usia remaja dan sebagai langkah penting menuju sosok pribadi dewasa yang produktif.

Pembentukan identitas ini merupakan tugas yang utama dalam perkembangan kepribadian yang diharapkan tercapai pada akhir masa remaja yaitu umur 18 - 21 tahun dalam Desmita. Walaupun tugas pembentukan identitas ini telah memiliki dasar-dasar pada masa anakanak, namun pada masa remaja ia menerima dimensi-dimensi baru karena berhadapan dengan perubahanperubahan fisik, kognitif, dan jiwa sosialnya. Selama masa remaja ini, kesadaran akan identitas menjadi lebih peka, karena remaja berusaha mencari identitas da mendefinisikan kembali "siapakah" ia saat ini dan akan menjadi "siapakah" ia pada masa yang akan datang. Perkembangan identitas selama masa remaja ini juga sangat penting karena memberikan suatu landasan bagi perkembangan psikososial dan hubungan interpersonal pada masa remaja dan dewasa. 
Begitu besarnya pengaruh pola asuh dalam kehidupan remaja perlu dikaji lebih dalam lagi. Pola asuh otoriter misalnya, membuat orang tua lebih mengarah kepada pembentukan erilaku negatif kepada anak, bisa membuat anak frustasi dan agresif. Sedangkan pola asuh yang demokratis lebih mengarah keada yang hal positif, seperti pembentukan identitas remaja. Peran orang tua dalam kehidupan remaja dapat dilihat dari bagaimana mereka menerapkan gaya pengasuhan dalam mendidik dan mengasuh anak. Pengasuhan yang tepat berlandaskan pada pengembangan dan pembentukan identitas pada remaja maka akan memberikan efek yang positif bagi remaja tersebut. Berdasarkan empat gaya pengasuhan yang akan dijelaskan, maka gaya pengasuhan yang memiliki potensi yang besar dalam pembentukan identitas, lebih khusus kepada pembentukan identitas remaja, khususnya identitas achievement.

Contoh penelitian di atas menunjukkan hasil pola pengasuhan orang tua yang gagal, anak kurang memiliki tujuan dan prinsip dalam bertutur kata, hal tersebut menunjukkan gagalnya orang tua dalam membentuk sikap dan perilaku anak yang positif dalam bersosialisasi. Di masyarakat secara umum termasuk Indonesia, terlihat kenyataan bahwa masih ada berbagai kondisi negatif yang terdapat dalam mayoritas keluarga orang tua tunggal. Misalnya, anak menjadi terlantar karena kurangnya perhatian, kondisi psikisnya yang cenderung lebih labil, kehilangan sosok panutan atau idola, dan harus ikut membantu orang tua mencati uang. Dari sisi orang tua tunggal sendiri di antaranya adalah adanya perasaan "sendiri" mnghadapi kehidupan, harus dapat bertahan dari cercaan, hinaan, perendahan, bahkan perasaan gagal dan kecewa dalam mengash anak yang dialaminya. Begitupun remaja yang mendapatkan pengasuhan dari orang tua tunggal, ia mulai bertanya tanya bagaimana kehidupannya kedepan, dan pekerjaan apa yang akan cocok dengan kualitas dirinya.

Remaja yang mengalami krisis identitas akan selalu merasa minder, apalagi jika yang berasal dari pengasuhan orang tua tunggal, berdasarkan hasil survey oleh Rahmat hasilnya $18 \%$ remaja tidak mengetahui tidak mengetahui tujuan hidup dan masa depan mereka dan $4 \%$ bingung menentukan tujuan hidupnya, dari hasil survey tersebut dapat disimpulkan bahwa sebagian remaja belum dapat menentukan dan memutuskan hal-hal yang berkaitan dengan masa depan dan hidup mereka, hal ini selaras dengan penggalian data awal yang dilakukan terhadap beberapa remaja disalah satu Mts Daarel-Qalam. sebagaimana yang dijelaskan oleh Moesono dalam Sawitri bahwa ternyata remaja tidak pernah benar-benar tahu apa yang diinginkan dalam hidupnya, tidak terbiasa tertantang dalam mencari 
informasi sampai tuntas, namun hanya bermodal informasi yang hanya $40 \%$ petunjuk orang tua.

Peran orang tua dalam pembentukan dan pengembangan identitas diri remaja memiliki peran yang sangat signifikan dan strategis. Akan tetapi, peran orang tua semakin hari semakin berkurang. Hal ini terlihat dari kurangnya komunikasi maupun salahnya pola asuh dari orang tua. Remaja sekarang lebih banyak menghabiskan waktu dengan teman sebayanya, baik dalam pergaulan sosial, membagi tanggunga jawab, maupun berbagi pengalaman dan informasi yang dibutuhkan remaja dari lingkungannya.

Berdasarkan permasalahanpermasalahan tersebut peneliti tertarik untuk mengetahui apakah ada hubungan antara pola asuh orang tua tunggal dengan pencapaian identitas diri achievement pada remaja. Mengingat pentingnya identitas achievement dalam pencapaian identitas diri remaja dan pentingnya faktor keluarga dalam proses pembentukan identitas diri, maka penelitian ini akan memfokuskan pada peran orang tua tunggal khususnya pola asuh dalam pembentukan dan pencapaian identitas achievement pada remaja.

\section{METODE PENELITIAN}

Kajian tentang pencapaian identitas remaja oleh orang tua tunggal perempuan di desa Kanigoro, Kab. Bantul ini bersifat lapangan (field research). Penelitian akan menggunakan metode kualitatif. Penentuan subyek penelitian dilakukan berdasarkan informan pada orang tua tunggal perempuan dengan ciri ditinggal oleh suami, bercerai, meninggal dunia, ataupun ditinggal mati oleh suami. Adapaun teknik pengumpulan data yaitu berupa wawancara mendalam, observasi dan dokumentasi.

\section{HASIL DAN PEMBAHASAN}

Setelah data yang diperoleh terkumpul lengkap, maka selanjutnya penulis akan melakukan analisis kualitiatif diskriptif untuk mengetahui keterkaitan atas teori dan data yang diperoleh, pembahasan ini akan menguraikan hasil penelitian tentang pencapaian identitas remaja oleh orang tua tunggal di desa Kanigoro, maka berikut keterangan penelitian baik itu pencapaian identitas, maupun pola asuh yang digunakan oleh orang tua tunggal tersebut:

Untuk memperoleh subyek penelitian, peneliti menindaklanjuti data tersebut kepada para kepala dukuh dan para otoritas dibawahnya dengan menggunakan empat kriteria utama permasalahan, yaitu:

a. Perempuan yang berstatus sebagai orang tua tunggal karena alasan perceraian.

b. Perempuan yang berstatus sebagai orang tua tunggal karena alasan kematian.

c. Perempuan yang berstatus sebagai orang tua tunggal dan beragama Islam 
d. Perempuan yang berstatus sebagai orang tua tunggal yang bekerja.

Berdasarkan hal tersebut, kemudian peneliti sesuaikan dengan kriteria-kriteria subyek yang akan diteliti, maka peneliti mendapatkan tujuh orang tua tunggal (perempuan) sebagai berikut:

Tabel 1.

Kriteria Subyek Penelitian Orang Tua Tunggal

\begin{tabular}{|c|l|c|}
\hline NO & KETERANGAN STATUS ORANG TUA TUNGGAL & JUMLAH \\
\hline 1 & ditinggal suami karena status cerai & 2 \\
\hline 2 & ditinggal suami karena status kematian & 3 \\
\hline 3 & ditinggalkan suami tanpa status perceraian & 1 \\
\hline 4 & orang tua tunggal perempuan perempuan dan bekerja & 1 \\
\hline 5 & tidak bersedia di interview & 5 \\
\hline 6 & bersedia untuk di interview & 3 \\
\hline JUMLAH & 15 \\
\hline
\end{tabular}

Dari enam keterangan tentang orang tua tunggal diatas, orang tua tunggal dengan keterangan tertentu ada yang peneliti tidak bisa interview semuanya, sesuai dengan keterangan dari tabel diatas. Oleh karena itu, dengan kata kunci tersebut dan berdasarkan kesesuaian dengan jumlah kriteria yang ingin diteliti, hanya beberapa saja yang bersedia untuk di interview dan ditindak lebih lanjut untuk diteliti. Ketiga orang tua tungga perempuan tersebut akan penulis bahas lebih lanjut dalam sub bab uraian hasil penelitian ini.

Namun sebelum menguraikan hasil penelitian ini, sebagai informasi awal peneliti mencantumkan beberapa keterangan tentang subyek peneliti atau narasumber.

Tabel 2

Informasi Narasumber Data Primer

\begin{tabular}{|l|l|l|l|l|l|l|l|}
\hline \multirow{2}{*}{$\begin{array}{c}\text { Nara- } \\
\text { sumber }\end{array}$} & \multicolumn{7}{|c|}{ Informasi } \\
\cline { 2 - 7 } & Umur & $\begin{array}{c}\text { Tingkat } \\
\text { Pendidikan }\end{array}$ & $\begin{array}{c}\text { Usia } \\
\text { Anak } \\
\text { Remaja }\end{array}$ & Pekerjaan & Alamat & $\begin{array}{c}\text { Lama } \\
\text { Menjadi } \\
\text { Orang Tua } \\
\text { Tunggal }\end{array}$ & Keterangan \\
\hline Darmini & $\begin{array}{l}48 \\
\text { Tahun }\end{array}$ & SMA & $\begin{array}{l}14 \\
\text { Tahun }\end{array}$ & Pedagang & $\begin{array}{l}\text { Dukuh } \\
\text { Kanigoro, } \\
\text { Rt.32 }\end{array}$ & 10 Tahun & Cerai \\
\hline Minullah & $\begin{array}{l}61 \\
\text { Tahun }\end{array}$ & SMA & $\begin{array}{l}32 \\
\text { Tahun }\end{array}$ & Petani & $\begin{array}{l}\text { Dukuh } \\
\text { Kanigoro, } \\
\text { Rt.32 }\end{array}$ & $\begin{array}{l}16 \\
\text { Tahun }\end{array}$ & $\begin{array}{l}\text { Meninggal } \\
\text { karena sakit }\end{array}$ \\
\hline $\begin{array}{l}51 \\
\text { Tahun }\end{array}$ & S1 & $\begin{array}{l}18 \\
\text { Tahun }\end{array}$ & Pegawai & $\begin{array}{l}\text { Dukuh } \\
\text { Kanigoro, } \\
\text { Rt.33 }\end{array}$ & 6 Tahun & Cerai \\
\hline
\end{tabular}




\section{Subyek Penelitian I}

Masalah awal masa menjadi orang tua tunggal adalah ketika ia harus menyesuaikan diri mengatasi masalah kenakalan anak, memenuhi kebutuhan keluarganya, sebab status yang disandangnya bukan hanya sebagai ibu bagi anak-anaknyam akan tetapi ia juga menjadi ayah bagi anak-anaknya. Oleh karena itu ia harus memiliki dua bentuk sikap, sebagai wanita yang harus menjadi ibu yang bersikap lembut terhadap anaknya, dan sebagai ayah yang harus tegas dan memberikan arahan-arahan yang bermanfaat bagi anaknya, serat berperan sebagai penegak keadilan bagi rumah tangganya. Ini sesuai kutipan wawancara berikut ini:

"ya awalnya terasa berat menyesuaikan dengan masyarakat sini mas, jadi bahan omongan tetangga, ada yang mendukung karena akhirnya udah gak sama suami, ada juga yang ngomongin jelek, hanya sekarang kan juga beda, pekerjaan yang biasanya beratberat yang suami kerjakan dulu, kini saya juga harus lakukan, ee terus ya mas, kudu sabar aja sama omongan orang, nanti juga mereka paham posisi saya, hanya yang saya nggak bisa nrimo kalau anak-anak saya diomongin mana bapaknya, saya suka kasian". (Darmini, 25/10/2017)

Menurut hasil pengamatan peneliti, yang dapat peneliti simpulkan ialah ibu Darmini menerapkan pola asuh permisif, ibu Darmini memanjakan anak dengan alasan kasih sayang kepada menuruti semua keinginan anak remajanya, ketika ankanya ingin membeli smartphone dan baju baju, ia rela membelikan uang, walau akhirnya anak ibu Darmini yang masih sekolah selalu merengek juga ingin dibelikan sesuatu, sampai pernah yang masih di sekolah dasar, merengek minta dibelikan sepatu baru ketika mengetahui kakaknya, membeli smartphone yang baru.

"ya mas, kebanyakan waktu saya di warung, anak yang bungsu saya titipkan ke mbahnya, dan menjelang maghrib saya ambil, dan lebih sering diajarin solat sama simbahnya, karena saya ngajar TPA di masjid hanya sore saja, tapi sekarang alhamdulillah dia udah pintar bacaaan shalat dikitdikit, hanya ya manja, minta apa aja saya belikan agar dia mau tinggal sama simbahnya, karena kalau saya bawa ke warung sering keluyuran disekitar tempat wisata, biarpun bapaknya sudah tidak tinggal disini lagi, saya masih bisa kok mas beliin mainan, jangan sampai dia nangis, jangan sampai dia kekurangan, kasian mas, dari kecil gini udah ditinggal bapaknya, kalau yang palig gede juga saya bebasin ntar kalau tamat SMA, mau lanjut kuliah opo nikah he..he..he" (Darmini, 25/10/2017) 
Penerapan gaya pendisiplinan seperti model ini terdapat kelonggaran pada anak yang sedang mereka didik, khususnya remaja, yang disaat tahap usia ini sedang aktifnya untuk mencari jati diri dan menemukan identitas dirinya. Seringkali orang tua justru tidak yakin pada kemampuannya untuk mendidik anak-anaknya secara baik, akibatnya, orang tua sering menjadi tidak konsisten. Ketidak konsistenan tersebut akan berakibat anak menjadi kurang percaya diri, anak merasa tidak bahagia, dan prestasi belajarnya bisa menjadi rendah, kelonggaran seperti ini biasa terjadi kepada anak remaja laki-laki.

Dari analisis ini ditemukan perbedaan yang signifikan bahwanya keterlibatan seorang ibu sangat penting dalam pencapaian identitas remaja, pola asuh yang tepat dapat membuat mereka menjadi pribadi yang sadar akan kebutuhan diri dan perannya di masa depan. Dengan adanya seorang ibu mereka akan menjadi pribadi yang lemah lembut dalam bertutur kata. Jika melihat pola pengasuhan ibu Darmini, maka dapat dikategorikan pola asuh ini adalah pola asuh yang salah karena memberikan kebebasan kepada anak, namun ketika berbuat salah, tidak ada peringatan ataupun hukuman dengan efek jera kepada anak tersebut.

\section{Subyek Penelitian II}

Ibu tunggal yang menjadi subjek penelitian yang kedua ini adalah Ibu Minullah, ia memiliki 1 orang anak bernama Ema Pertiwi, biasa juga dipanggil masyarakat sekitar dengan panggilan ibu Minul, ibu minul dalam usianya yang seudah memasuk 61 tahun, ia setiap harinya bekerja di perkebunan tebu milik Pak Sunardi, setiap hari ia bekerja untuk kebutuhan sehari harinya, karena anaknya yang pertama sudah tidak tinggal bersamanya lagi setelah menikah dengan perempuan asal desa Playen Wonosari.

Ibu Minullah ini sudah menjadi orang tua tunggal perempuan selama 16 tahun lamanya, dan anaknya pun semua sudah berkeluarga, namun banyak pengorbanan yang ia berikan kepada anak-anaknya, dan juga ibu Minullah ini selalu memberikan peraturan-peraturan yang tidak terikat atau bebas kepada anak-anaknya, ia mengharuskan anaknya untuk mandiri dimanapun mereka berada, dulu sewaktu kecil, ayah anak-anaknya selalu mengajakan pendidikan agama kepada anak-anaknya, ini bertujuan agar anaknya dapat selalu beribadah dimanapun mereka berada.

"sewaktu kecil, ini anak-anak selalu diajarin ngaji sama bapaknya, dulu kalau maghrib, harus belajar ngaji sama bapaknya, kalau nggak ya bisa dihukum sama bapaknya, pokoknya kalau sudah masalah solat atau ibadah itu yang ngajarin bapaknya, kalau saya hanya bisa ngajarin sopan santun mas, karena saya sendiri nggak terlalu bisa membaca al-Qur'an. Makanya sampai sekarang anakanak sangat lancar membaca al'Qur-an." 27/10/2017) 
Hingga anaknya semua sudah tidak lagi tinggal bersamanya, ia selalu berpesan bahwa dimanapun anak-anaknya berada, harus selalu mengingat bahwa apa yang telah diajarkan oleh ayah mereka selalu teringat. Ibu Minul menerapkan pola asuh yang demokratis kepada anakanaknya, khususnya kepada yang anak pertama, ibu Minul memberikan peraturan bahwa anaknya yang perempuan harus bisa menjadi wanita yang mandiri, supaya bersiap untuk memberikan pendidikan kepada anakanaknya, sampai pada saat anaknya ini ingin berhenti sekolah setelah lulus SMP, ia mewajibkan bahwa anaknya tersebut masih harus melanjutkan pendidikan sampai SMA, karena jika hanya sampai SMP jarang yang dapat menerima untuk memberikan lapangan pekerjaan.

"dulu mas pada saat anak saya minta berhenti untuk sekolah ya saya diamkan, nggak saya beri makan, biar dia tau kalau cari duit itu susah, biar nggak kayak saya, harus jadi petani karena nggak bisa membaca dan menulis" 27/10/2017).

Dari penuturan ibu Minul ini, bisa disimpulkan bahwa ia tidak memaksakan kehendak kepada anakanaknya, namun masih dengan tujuan agar anak-anaknya menjadi manusia yang bisa bertahan dimasa depan, minimal bisa membaca dan menulis, begitulah harapan ibu Minul kepada anak-anaknya. Namun dengan peraturan tersebut anaknya menjadi dekat dan terbuka kepada ibu Minul sendiri. Kebiasaan anak-anaknya yang bermain ke teman sebayanya juga tidak dibatasi oleh ibu Minul sendiri, ini bermula pada saat anaknya rebutan mainan, dan anak tetangganya itu menangis karena mainan yang diperebutkan itu jatuh dan rusak, dan ibu Minul enggan untuk memberikan ganti. Namun karena melihat kelakuan anaknya, ia harus mengganti barang tersebut sebagai bentuk pertanggung jawaban ibu Minul sebagai seorang ibu, dari pengalamn itulah, ia memberikan contoh bahwa ketika ia melakukan sesuatu kesalahan, maka ia harus bertanggung jawab, ia boleh bergaul dengan siapapun, hanya harus bisa melihat kondisi dan mempertanggung jawabkan apa yang diperbuatnya .

Papalia, mengemukakan bahwa hubungan remaja dan orang tuanya, dipengaruhi oleh situasi kehidupan orang tuanya itu sendiri, diantaranya status pernikahan, pekerjaan, dan keadaan sosial masyarakat. Hubungan ini memiliki peran terhadap pola pengasuhan yang diterapkan oleh orang tua kepada remaja. Dari pola asuh yang diterapkan ibu Minul ini, ia sangat mengerti bahwa semua aturan yang diberikan adalah demi kebaikan anak-anaknya, karena dengan memberikan pola asuh yang bebas atau demokratif, maka ia dapat memilih mana yang nantinya ia jalani dan mana yang harus ia hindari. Semua kebebasan yang ia berikan 
kepada anaknya dengan harapan dapat menjadi apa yang mereka cita-citakan, namun tetap dalam lingkaran atau peraturan. Kekuragan ataupun kesulitan ibu Minul kerap menjadi perhatian saudara-saudaranya, naumn terkadang ia menolak untuk menerima segala perhatian dan bantuan dari saudara-saudaranya yang lain.

Dari beberapa penuturan yang diberikan ibu Minul, ia merasa bahwa dengan memberikan kebebasan untuk memilih apa yang mereka ingini, maka ia lebih lega dan melihat anaknya menjadi lebih bertanggung jawab dan dewasa dalam melihat permasalahan yang ada. Memutuskan suatu pekerjaan pun selalu berserita dengannya, tidak menjadi pribadi yang tertutup dan menjadi kebanggaan tersendiri bagi anak-anaknya dan ibu minul sendiri. Dengan kesimpulan ini bisa disimpulkan bahwa pola asuh demokratis yang diterapkan oleh ibu minul dapat menjadi salah satu pola asuh yang baik, khususnya kepada ibu tunggal dengan tujuan tidak mengekang, sehingga remaja dapat mengeksplorasi masa krisisnya dengan baik.

Sesuai penuturan teori yang dikemukakan oleh Chabib Toha, pola asuh demokratis ini ditandai dengan adanya pengakuan kepada anak, anak diberi kesempatan bereksplorasi dengan tujuan mandiri, dan tidak selalu bergantung kepada orang tua. Adanya sedikit kebebasan yang diberikan orang tua untuk memilih apa yang terbaik bagi dirinya, anak juga didengarkan pendapatnya, anak juga dilibatkan dalam pembicaraan yang berkaitan dengan masa depan anak itu sendiri, memberikan pujian ketika mereka mendapatkan prestasi. Dengan kebebasan ini, bukan berarti mereka berbuat sesuka hati, namun tetap dalam kontrol.

Pola asuh demokratis ini juga biasa dikenal dengan pola asuh autoritatif, gaya pengasuhan yang disiplin, tegas, keras, menuntut, mengawasi, namun konsisten dan penuh kasih sayang. Pola asuh yang ibu Minul berikan kepada anaknya ini menjadi sangat tepat, karena mau mendengarkan perkataan anaknya, dan menjelaskan apa yang tidak dan boleh mereka kerjakan. Pola pengasuhan seperti ini dapat menghasilkan anak yang mempunyai kepercayaan diri dan harga diri yang tinggi. Ditinjau dari segi pencapaian identitasya, dapat menjadi lebih mudah untuk menjalankan perannya sebagai remaja. Mampu bergaul dengan sebayanya dengan baik.

\section{Subyek Penelitian III}

Adapun narasumber yang terakhir diwawancarai oleh peneliti ialah Ibu Jumianti. Ibu Jumianti hingga saat ini berprofesi sebagai pegawai swasta di Pegadaian. Ibu Jumianti mempunyai dua orang anak laki-laki, yang tertua bernama Dadang kini berprofesi sebagai teknisi listrik di kantor PLN. Ibu Jumianti sudah enam tahun menjadi ibu Tunggal, adapun penyebabnya adalah cerai dari 
suaminya. Dulu, suami ibu Jumianti ini bekerja sebagai pemilik toko furniture di Desa Mangunan, dan sesekali suami ibu Jumianti pergi ke Bali untuk melihat kondisi cabang tokonya yang ada disana, karena seringnya pergi ke bali maka ia pun menikah dengan orang Bali tersebut dan tidak lagi menetap di Kanigoro setelah bercerai dengan ibu Jumianti. Dari sifat buruk suaminya itulah yang menjadi beban mental dan awalnya ibu Jumianti memutuskan untuk bercerai dan tetap tinggal di Kanigoro bersama anaknya. di awal awal ibu Jumianti menjadi ibu tunggal, banyak cemohan dari masyarakat karena prilaku suaminya. Tidak sedikit yang tidak mau mengajak ibu Jumianti untuk ikut serta dalam kegiatan kampung, seperti pengajian, arisan maupun kerja bakti, terkecuali saudaranya yang masih sering menengoknya dan melihat kondisi tersebut juga mereka menghawatirkan ibu Jumianti.

"dari pihak keluarga saya ada yang membantu ketika saya sedang kesulitan, namun saya yang biasa rada tidak enakan kalau terus-terusan dibantu, saya juga kan kerja jadi sebisa mungkin kalau masalah ekonomi saya atasi sendiri, hanya kalau masalah anak-anak biasa saya bebaskan aja maunya seperti apa, mau lanjut sekolah apa kuliah terserah, asal mereka sadar, kalau nggak kuliah nggak bisa dapat/susah nyari pekerjaan. Sedangkan kalau masalah bantuan, materi ya gitu tadi mas saya nggak bisa langsung nerima begitu saja, biasa saya tolak, dalam hati kita kan ada prinsipprinsip tertentu, tapi bukan nggak mau nerima ya mas hanya lebih berhati-hati aja." (Jumianti, 2/11/2017)

Karena ke khawatiran ibu Jumianti ini terhadap anaknya, ia menerapkan aturan yang ketat, dan kemauannya harus diikuti, yakni harus bersekolah. Terutama kepada anaknya yang tertua, sangat ia tekankan bahwa tidak boleh putus hanya sampai SMK saja, akan tetapi harus sampai lulus di Universitas dan mendapatkan jaminan pekerjaan, sedangkan anaknya yang kedua, ia lebih cenderung pendiam dan mengikuti aturan dan peritah dari ibunya. Lebih sering ia menghabiskan waktu dirumah, dan jarang juga ia meminta sesuatu seperti minta dibelikan mainan atau pakaian.

Kemandirian dari anak-anak bu Jumianti ini memang berbeda-beda, dari sang kakak yang masih cenderung melawan peraturan yang diberikan ibunya, dia merasa bahwa sudah tidak kecil lagi jadi harus bebas melakukan apapun yang diminatinya, ia saat sekolah sangat menekuni bidang musik, namun berpindah haluan menjadi teknisi PLN karena saat kuliah ia mengambil jurusan Teknik Elektro. Namun tidak sedikit perkataan ibunya ada benarnya juga, bahwa ia harus mempunyai pekerjaan yang tetap dan menjadi orang yang bertanggung jawab bagi keluarganya kelak. 
"sehingga mereka kelak akan menjadi anak berguna ya, berguna bukan hanya didunia saja, tetapi juga untuk kebaikan mereka di akhirat kelak. Jadi ya harus legowo apa kata saya, kalau mau jadi orang ya harus nurut, jangan seperti bapaknya" (Jumianti, 2/11/2017).

Melihat hasil analisis dari pengasuhan ibu Jumianti kepada anaknya memang terlalu berlebihan, remaja dituntuk untuk menyesuaikan diri dengan kemauan dan perintah sang ibu, bahkan juga harus berlawanan apa yang menjadi kemauan anak tersebut dan apa yang menjadi kemauan orang tua. Oleh karena itu pola asuh yang otoritatif seperti ini bisa saja membuat pribadi yang rumit dan identitasnya bisa saja salah menjadi identitas difusi.

Harapan dan peraturan yang memang keras kepada anak-anaknya hanyalah bertujuan untuk kebaikan mereka di masa depan, karena untuk menghilangkan rasa trauma akan orang yang tidak berpendidikan, ia merasa anaknya harus bersekolah tinggi, kemauannya harus dituruti, walaupun berefek yang tidak sesuai kepada anaknya, menjadi pendiam, tertutup bahkan minat dan bakat yang dimiliki sang anak tak mendapat dukungan dari ibunya.

Pengalaman hidup dan tinggal bersama orang tua dalam pola asuh yang diterapkan, dapat memberikan pengalaman yang bersifat psikologis, praktis dan dapat dijadikan informasi tambahan ketika remaja yang akan dewasa menentukan pilihan hidupnya sendiri, dapat dijadikan gambaran ketika ia akan memilih dan menentukan keputusannya sendiri, dan memberikan jaminan masa depan. Maka dengan demikian, sangat mungkin dari pola asuh tersebut berpengaruh kepada pilihan hidup remaja tersebut. Eksplorasi diri yang ada pada diri mereka, dapat mereka atasi dengan pencapaian identitas yang baik dan sukses (identity achievement) Eksplorasi dan komitmen merupakan bagian identitas yang dapat digunakan untuk melihat dan mengukur perkembangan status identitas seseorang tersebut, baik itu difussion, foreclosure, moratorium atau achievement. Pencapaian identitas masing-masing bisa berbeda, tergantung dari pola asuh orang tua.

\section{KESIMPULAN}

Berdasarkan hasil penelitian yang telah dilakukan peneliti, ada beberapa hal yang bisa disimpulkan, yaitu:

1. Pencapaian identitas remaja, khususnya identitas Achievement, dipengaruhi oleh beberapa aspek, dan salah satunya adalah pola asuh. Dalam penelitian ini, gambaran pola asuh demokratis yang diterapkan oleh ibu Minul adalah pola asuh yang tepat kepada anaknya. Setiap orang tua, memiliki cara mendidik dan mengasuh dengan pola yang berbeda-beda. Khususnya orang 
tua tunggal dari subyek penelitian di desa Kanigoro ini, ia harus memiliki dua bentuk sikap, sebagai perempuan yang harus menjadi ibu yang bersikap lembut terhadap anaknya, dan sebagai ayah yang harus tegas dan memberikan arahan-arahan yang bermanfaat bagi anaknya, serat berperan sebagai penegak keadilan bagi rumah tangganya..

2. Berdasarkan hasil penelitian, pola asuh yang diterapkan ibu Minul di Kanigoro ini menunjukkan pola asuh demokrasi. Memberikan kebebasan bereksplorasi kepada anaknya, dengan tetap bertanggung jawab terhadap diri sendiri dan perbuatannya. Terbuka kepada anak, baik itu masalah ekonomi, moral, keagamaan semuanya selalu didiskusikan bersama-sama, sehingga anak pun menjadi lebih terbuka dan keinginannya selalu ia berusaha mendukung dan mewujudkannya.

\section{SARAN}

Berdasarkan hasil penelitian, analisis, dan kesimpulan ada beberapa saran yang peneliti sarankan:

1. Untuk peneliti selanjutnya

a) Menambahkan beberapa faktor untuk penelitian, seperti bagaimana solusi untuk orang tua tunggal yang masih susah untuk bangkit dari permasalahannya.

b) Menambah variabel penelitian, khususnya untuk orang tua tunggal, agar banyak solusi yang ditawarkan dalam pemecahan masalah.

2. Untuk orang tua tunggal, khususnya perempuan.

a) Orang tua tunggal perlu memperhatikan faktor usia dan perkembangan remaja, karena perkembangan dan usia remaja sangat berpengaruh juga dengan pola asuh yang digunakan dalam peneraannya, sehingga anak remaja dapat mencapai identitas achievement dengan baik.

b) Sebaiknya anak sering diajak diskusi dalam masalah keluarga, sehingga anak dapat menjadi lebih terbuka juga dalam permasalahan apa yang dirasakannya, semakin ia menjadi matag dalam perkembangannya, semakin besar rasa tanggung jawab yang dimiliki. Semakin dekat orang tua dengan anak, khususnya remaja ia lebih dapat mengerti pentingnya sebuat pendekatan dan interaksi antara orang tua dan anak.

c) Pola asuh yang salah dapat menghasilkan generasi remaja yang rumit dan tua, dampak yang bisa dihasilkan adalah ia dikhawatirkan menjadi pribadi yang pembangkang jika terlalu dikekang. Jangan menjadikan anak sebagai "warisan" warisan yang 
dimaksudkan disini adalah mencontoh pola asuh yang ia dapatkan dari orang tuanya dahulu, akan tetapi harus menyesuaikan dengan perkembangan zaman dan keadaan anak tersebut.

3. Untuk masyarakat.

a) Perlunya rasa tenggang rasa kepada orang tua tunggal, karena dengan adanya dukungan sosial, dapat memudahkan pelaksanaan pengasuhan anak, baik itu yang berpisah dengan suaminya dengan perceraian ataupun kematian, karena masing masing memiliki tingkat kesabaran dan kekuatan untuk menghadaoi masalah yang dihadapi dengan berbeda-beda.

b) Kepala daerah setempat dan jajarannya harus lebih memerhatikan lagi warganya, setiap kegiatan secara gotong royong, kegiatan kerohanian supaya tidak adalagi intervensi dan penolakan kepada mereka yang mengalami dari kehilangan pasangan, khususnya para orang tua tunggal perempuan.

\section{DAFTAR PUSTAKA}

Balson, M. 1999. Becoming Better Parents Edisi ke-4. Terjemahan Sr. Alberta.Grasindo. Jakarta.
Brooks, Jane. 2011. The Process of Parenting (proses Pengasuhan). Edisi Kedelapan. Yogyakarta: Pustaka Pelajar.

Chaplin, C,P. 2005. Kamus Lengkap Psikologi (alih bahasa: Kartono,K), Edisi I, Cetakan ke7. Jakarta. Grafindo Pustaka

Dariyo Agus. 2004. Psikologi Perkembangan Remaja. Bogor Selatan: Penerbit Ghalia Indonesia

Gunarsa, D. 1997. Dasar dan Teori Perkembangan Anak: Jakarta: BPK. Gunung Mulia.

Hurlock, E.B. 1987. Perkembangan Anak Jilid II, Erlangga: Jakarta.

Kelly Musick. 2002. "Planned and Unplanned Childbearing Among Unmarried Woman," Journal of Marriage and Family 64: 915929.

Marcia, James E. 1993. Handbook of Adolescence Psychology. J. Adelson. New York: Wiley \& Sons

Moleong. 2007. Metode Penelitian Kualitatif. Bandung: PT.Remaja Rosdakarya.

Monks, dkk., 2001. Psikologi Perkembangan. Yogyakarta: Gajahmada University Press. 